\title{
Facebook Utilisation to Enhance English Writing Skill
}

\author{
Sabaruddin ${ }^{1}$ \\ ${ }^{1}$ Faculty of Education, Monash University, Australia \\ Correspondence: Sabaruddin, Faculty of Education, Monash University, Australia.
}

Received: June 1, 2019 Accepted: July 7, 2019 Online Published: July 9, 2019

doi: 10.5539/elt.v12n8p37 URL: https://doi.org/10.5539/elt.v12n8p37

\begin{abstract}
This paper aims to investigate the use of Facebook in enhancing English writing skill of Indonesian students in the secondary high school context. The result of this research is hopefully beneficial to overcome English writing difficulties of secondary high school students in Indonesia. The discussion informs that Facebook utilisation in teaching writing improves learners motivation to write in English, increases grammar mastery of the students, and provides abundant learning materials for the learners to develop their English writing ability. The result of this study will be useful as a reference for English teachers to adjust Facebook use into their teaching practice in order to help students in improving their English writing skill.
\end{abstract}

Keywords: English teaching strategy, Facebook use, English writing skill

\section{Introduction}

\subsection{Problem}

Having an ability to write in English is essential for students in this globalisation era. Writing is a skill to formulate and organise ideas in the right words to transform and communicate the purpose to the reader by presenting it on a piece of paper (Sumarsih \& Sanjaya, 2013). This skill is valuable to be mastered by students because writing facilitates learners to express themselves and explain their thoughts to others (Sharples, 1999). By having the ability to write in English, students can transform messages or ideas to the reader across the globe (Brown, 2007). Therefore, equipping students with English writing skill is highly needed to assist them to be more competitive in this latest era.

\subsection{Importance of the Problem}

However, students in Indonesia face a significant obstacle in writing English. Students in Indonesia assume that the writing process is stressful and arduous (Purwanti, 2015). Megawati and Anugrahwati (2012) conducted a study in MAN Bangil, one of secondary high school in Indonesia, and report that students seem unenthusiastic and have troubles in constructing their writings. The challenges of students are due to some factors such as learners' little interest in English, limited vocabulary and grammar understanding of students, monotonic teaching technique applied by the English educators, and absence of instructional media (Megawati \& Anugrahwati, 2012).

\subsection{Relevant Scholarship}

Facebook is a kind of networking site used for information sharing, networking and communication and some features of this site can be utilised for teaching purpose (Barrot, 2016). For example, the Facebook wall can be used to share learning material and post students' works. There have been many studies depicting the advantages of Facebook utilisation in English language teaching. For instance, a study conducted by Tananuraksakul (2015) reports that the use of the Facebook group makes the learning process enjoyable and improve students' enthusiasm to learn English. Furthermore, the Facebook group provides plenty of occasions for students to practice and to enhance their writing competence (Ping \& Maniam, 2015; Yunus, Salehi, Sun, Yen, \& Li, 2011). Therefore, Facebook utilisation could be beneficial to help secondary high school students in Indonesia to develop their writing competence.

\subsection{Main Argument}

This essay will investigate critically the effectiveness of Facebook utilisation in improving English writing skill of Indonesian students in secondary high school context by considering the challenges and some possible ways to encounter the obstacles to responding the issues explained above. In this essay, I would like to argue that 
using Facebook in English Language teaching is useful to enhance students' writing skill. This essay begins by providing background information related to Facebook usage in language teaching and explaining the significance of this study. Research questions, method, and outline of key ideas are also stated before deeply examining the benefits of Facebook utilisation in improving students' English writing skill. In the end, this essay will be concluded based on the overall explanation, and some recommendations are also stated for further investigation.

\subsection{Research Questions}

Three research questions are formulated to understand the purpose of this study, as follows:

- What are the benefits of Facebook utilisation on students' writing skill?

- What are the challenges of using Facebook to enhance students writing skill in Indonesia?

- How can the challenges of Facebook usage be solved?

\subsection{Significance}

This investigation is hopefully beneficial to overcome the writing difficulties faced by secondary high school students in Indonesia. The result of this study would be useful as a reference for English teachers in Indonesia to adjust the use of Facebook into their teaching practice to enhance students' English writing competence. The finding will also be applicable for English educational researchers who are interested in Facebook utilisation to investigate more Facebook usage in language teaching.

\section{Method}

A critical review of relevant literature is used in this study. Before investigating the issue, some academic literature which is relevant to Facebook utilisation in language teaching and English writing skill is gathered and selected. The literature was collected from many kinds of resources such as articles from reputable academic journals as well as books. The chosen literature was then analysed and evaluated critically to find the information needed. Lastly, the suitable information and evidence were used to construct arguments in this essay.

Three benefits of Facebook on the improvement of students writing ability will be examined. Firstly, this essay discusses the benefits of Facebook usage that links to the students' motivation. Secondly, it explains the advantage of Facebook concerning the students' grammar understanding. Thirdly, it focuses on discussing the benefit of Facebook to enrich students' instructional materials. Each of the three aspects is followed by counter-arguments and refutations as well.

\section{Discussion}

\subsection{Increasing Students' Motivation to Write in English}

The first benefit of using Facebook in teaching English writing skill is that it develops the motivation of the students to practice their writing. Motivation is a combination of effort, desire, and satisfaction, which is influenced by internal and external factors (Woolfolk, 2001). According to Dja'far, Cahyono, and Bashtomi (2016), motivation is one of the factors that determine the learning achievement of learners. If students feel motivated, they tend to put the best effort in their study (Tananuraksakul, 2014). Thus, having a high motivation to write in English, students are supposed to develop their writing skill. However, according to the study of Megawati and Anugrahwati (2012), students in Indonesia seem unmotivated to learn English writing. They argue that this condition is caused by monotonous teaching methods or techniques utilised English teachers. As a result, students cannot adequately improve their English writing competence (Megawati \& Anugrahwati, 2012). Utilising Facebook, as a media of teaching English writing, could be a suitable solution for this issue. Kabilan et al.'s (2010) study underpin that utilising Facebook for teaching English writing can enhance students motivation to write. It is because Facebook creates simplicity in learning (Gamble \& Wilkins, 2014). For instance, the students can practice writing wherever they are and post their writing directly on their Facebook wall. The teacher and other students can also comment and give feedback to other students' work synchronously or asynchronously, so there is no need for the students to type their writing on a piece of paper and ask their tutor for correction (Gamble \& Wilkins, 2014). This instant interaction and feedback increased writing motivation of the students (Yunus \& Salehi, 2012). Besides creating learning simplicity, Facebook also promotes a comfortable learning environment (Majid, Stapa, \& Keong, 2012). Online learning on Facebook is different from the traditional way of teaching (face-to-face classroom) where some learners usually feel anxious to write because of the presence of instructor that sometimes make the students fell intimidated (Tananuraksakul, 2014). The online learning environment created by Facebook makes the students feel comfortable to write and 
encourage them to participate actively (Tananuraksakul, 2014). Therefore, using Facebook in teaching English writing skill is recommended for English teachers in Indonesia to improve students' motivation in English writing.

However, utilising Facebook to enhance students' writing motivation encounters some problems. The first is that low-speed internet connection hinders the students from enjoying the learning simplicity and convenience offered by Facebook. For example, because of internet trouble, the students unable to post their writing directly to their Facebook, and sometimes they have to repeat their work submission. Barrot (2016) reports that students feel discomfort in using Facebook in learning due to a slow internet connection. Students also considered internet interruption as a hindrance to connect to others and to be able to contribute actively to online interaction (Yunus et al., 2011). Consequently, rising students writing motivation using Facebook becomes harder due to internet trouble. The second problem is that several students cannot enjoy online learning because they are used to studying using conventional teaching method. Since they are accustomed to the traditional way of teaching, they experience some problems to use Facebook in learning English writing (Barrot, 2016). For instance, a study conducted by Barrot (2016) informs that some students fell a burden to type their essay online because they are used to writing by hand, and several students are challenging to read relatively small texts which are posted on the Facebook wall. Another research also depicts that students do not contribute actively to online learning conducted using Facebook since they feel face-to-face interaction in the classroom is more efficient ( $\mathrm{Yu}, 2014)$. Thus, the use of Facebook to enhance writing motivation of learners seems useless because of internet connection issue and little interest of students in online learning.

To overcome such issues stated above, providing an accessible online network in school is suggested for stakeholders (headmaster or English teacher). For example, installing an internet provider in the school so that students can connect to the internet easily. This is supported by an argument of Bosch (2009) saying that one possible solution for using Facebook effectively in teaching would be to provide a good internet connection in an educational institution. Hence, the simple and comfortable learning setting on Facebook can be enjoyed by students as they can communicate with their teacher or peer easily and collect their writing instantly. In order to change the attitude of English learners who prefer the traditional way of teaching rather than online learning, the teacher can conduct scaffolding before the learning process ( $\mathrm{Yu}, 2014)$. Scaffolding is a learning approach which is designed to develop students' learning understanding by explaining the learning procedure and giving guidance and support to achieve students learning goal (Tiantong \& Teemuangsai, 2013). For instance, before conducting teaching through Facebook, an English teacher should explain the usefulness of using such kinds of application in learning English writing. The English teacher should also inform the learning steps using features on Facebook. After that, students are exposed and devoted to online learning activities on Facebook. Based on research formulated by Yu (2014), by doing so, the students gradually accept online learning and become excited to participate in the learning processes. Hence, the student mindset who are used to interacting in a face-to-face classroom is changed through the scaffolding. As a result, they are willing to involve in online learning on Facebook. In brief, even though some issues appear in relation to Facebook utilisation in teaching English writing skill, all the problems could be solved by treating those problems appropriately. Therefore, Facebook can be utilised as a teaching and learning media in order to improve students' motivation in English writing.

\subsection{Enhancing Students' Grammar Understanding}

Besides developing students' motivation to write in English, Facebook utilisation also contributes to the improvement of students' grammar understanding. Grammar is "the set of rules that describe the structure of a language and control the way that sentences are formed" (Macmillandictionary.com, 2017). Individuals can communicate using the same language because they recognise and understand the grammatical structures of the language (Shen, 2012). It means that grammar understanding plays an important role not only in speaking but also in writing. According to Suthiwartnarueput and Wasanasomsithi (2012), the grammatical competence of students has a significant contribution to their writing skill. However, Megawati and Anugrahwati (2012) report that students in Indonesia struggle with their grammar understanding, which disadvantages them to write in English correctly. Thus, boosting Indonesian students to master English grammar is essential for assisting them to produce a good quality of English writing. Using Facebook in teaching English writing skill could become a possible strategy to develop learners' grammar. It is because Facebook can facilitate peer-to-peer assessment among learners (Yunus \& Salehi, 2012). Peer assessment or peer feedback is defined as a way of evaluating and providing feedback on peers' work (Wang, 2016). Through interaction with other students in the Facebook discussion, students enable to assess and give feedback to other students' essay (Ekoç, 2014). Moreover, English learners' participation and interaction with other learners through posting and commenting assist to improve their writing quality (Razak, Saeed, \& Ahmad, 2013). For example, using the comment feature on Facebook, 
students are able to give questions and comments on other students writings or essays. In this discussion, students can offer and also get corrections in terms of grammatical errors of their articles. An intense debate on grammar errors found in their English writing eventually improves their grammar understanding. This notion is also affirmed by Shih (2011), arguing that grammar mastery of students is developed through peer evaluation. Hence, utilising Facebook in teaching English writing skill is recommended for English instructors In Indonesia.

Nevertheless, peer evaluation facilitated on Facebook cannot fully benefit the enhancement of students English grammar competence because of some issues. The first is related to the student's confidence. If the students are not confident enough, they feel uncomfortable with comments from their friends. For example, the research study done by Alm (2015) reports that several students are worried to submit their writing on Facebook since they are insecure and afraid to be criticised for their works. Thus, grammatical errors in their essay cannot be evaluated and identified by their peers. Moreover, the level of English proficiency of students impacts the process of peer feedback. For instance, some students seem challenging to understand their friends' feedback because they do not know the meaning of the comments (Kabilan et al., 2010). They also struggle with giving explicit remarks because they have limited vocabulary (Yu, 2014). Furthermore, low students' involvement in providing explanations to others determines the success of peer feedback conducted on Facebook. This notion is rectified by research formulated by Ekoc (2014), informing that some students are not willing to engage actively in the online discussion on Facebook. Other learners make up simple comment (good or bad) without fully evaluate other students' essays because of laziness (Barrot, 2016). Enhancing English grammar of students through peer assessment on Facebook looks ineffective because of some difficulties above.

In order to maximise the benefit of peer-to-peer evaluation on the advancement of the English grammar of students, some possible solutions are offered. Firstly, teachers are recommended to give explicit instruction about learning objectives and outcomes using Facebook in order to boost the students' confidence to contribute more to the peer-evaluation process. For instance, the teachers should inform what the students should write, when they have to submit their writing and why they are suggested to give comments. Knowing the objectives and outcomes of the learning process, students become more confident (Gamble \& Wilkins, 2014). Secondly, the teachers can use a grading system for every comment posted by students to encourage the active involvement of students in an online discussion. Study handled by Yu (2014) finds that giving a score to learners who post comments to their friend increase the participation of learners in an online discussion. Lastly, allowing students to use online dictionaries and online translation tools which can be accessed while using Facebook helps students with a low level of English proficiency to take apart on peer feedback activity (Alm, 2015). By way of illustration, students can search unknown vocabularies to construct their essays or feedbacks using an online dictionary before posting them on Facebook. Utilising online translation tools also assist students in understanding their peers' feedback quickly. Based on a study run by Kabilan et al. (2010) using such online tools intensely, the beginner students enhance their English proficiency. Although there are several obstacles to escalate the English grammar of students using peer-to-peer evaluation on Facebook, those barriers could be minimised through appropriate solutions. Therefore, considering those issues and applying proper treatments to overcome the problems, English educators in Indonesia can utilise Facebook to develop English grammar understanding of students efficiently.

\subsection{Enriching Students' Learning Resource}

Apart from enhancing the grammar competence of students, using Facebook in language teaching also enriches the instructional materials of students. Instructional materials are "educational resources used to improve students' knowledge, abilities, and skills" (Thefreedictionary.com, 2017). Having sufficient learning materials, students have a chance to develop their knowledge maximally (Taffs \& Holt, 2013). One of the problems encountered by students in Indonesia to improve their writing skill is the limited number of instructional materials in school (Megawati \& Anugrahwati, 2012). Using Facebook could be beneficial to serve the students with plenty learning sources since the students, as well as the instructors enable to share many kinds of information related to English writing such as texts, videos, links to English tutorial programs (Ekoc, 2014; Haverback, 2009). As a case in point, English instructors and learners can post links to YouTube videos which contain ample tutorials about English writing or links of English language learning websites such as Britishcouncil.org that can be used to learn English writing. They can easily share the links by copying the links and posting them on their Facebook group. Therefore, through Facebook, the problems of students in Indonesia regarding the absence of instructional materials could be overcome. Having an opportunity to access rich learning sources through Facebook, hopefully, will enable students in Indonesia to increase their English writing skill.

Even though students are provided many kinds of English learning sources on Facebook, it does not guarantee 
that they will learn maximally. There are many features, links, and applications that can be accessed on Facebook, and that stuff is possible to distract students' concentration to learn (Yunus et al., 2011). As an example, students might delay watching the video shared by their teacher or peer as they enjoy playing online games or chatting with their friends on Facebook. Another issue of sharing learning sources on Facebook is that the quality of instructional materials posted by students. Several students might not read or watch the instructional materials before they share them with their friends (Yunus et al., 2011). Hence, the proper solution is needed to minimise such issues.

To refute the arguments above, integrating the applications such as games on Facebook in the process of learning is proposed for English teachers since the students could develop their English as well by online games based English. According to a study conducted by Kabilan et al. (2010), playing games on Facebook necessitates students to recognise the instruction in English. It means that games on Facebook are not always influenced negatively on the students, but those also give positive impacts in terms of their English language development. Thus, interrelating games on Facebook in learning activities are suggested to keep students' learning focus. Furthermore, to make sure that students share reliable learning materials on Facebook, asking the students to check videos, or links before uploading them to the Facebook group is suggested (Yunus et al., 2011). Therefore, instructional materials which are posted by students are used to assist them in improving their writing skill. All in all, connecting online games and advising students to share reliable learning sources on Facebook, English teachers in Indonesia could help the students regarding providing available instructional materials.

\section{Conclusion}

In conclusion, Facebook utilisation might be practical to improve secondary high school students' English writing skill in Indonesia because of three reasons. The first reason is that using Facebook in teaching English writing skill can increase the motivation of learners to practice their English writing as Facebook creates learning simplicity and convenience. Thus, little interest of students in English writing could be overcome using Facebook. Moreover, Facebook utilisation in teaching English writing enhances students' grammar understanding because learners can give and provide feedback regarding their grammar errors found in their writing. Hence, receiving many corrections from their friends as well as their teachers, the students can evaluate their works resulting in increment their grammar mastery.

Furthermore, Facebook usage, as a media of teaching provides students with ample instructional materials to learn English writing skill. It is because Facebook can facilitate the students to share and to access learning materials through Facebook. Thus, the problem of students in Indonesia regarding the limited instructional materials could be minimised. By having abundant learning sources, students are supposed to develop their English writing skill. Even though some challenges are encountered in utilising Facebook in teaching English writing skill, English teachers in Indonesia can use Facebook to teach English writing efficiently by considering some possible solutions which are offered in this paper. Therefore, utilising Facebook as a means of teaching English writing is useful to enhance students English writing skill, and it is proposed for English educators to use Facebook in their teaching practice in order to strengthen English writing skill of students in Indonesia.

\section{Acknowledgments}

I would like to acknowledge the Indonesian Endowment Fund for Education (LPDP) for the grant given to the author.

\section{References}

Alm, A. (2015). Facebook for informal language learning: Perspectives from tertiary language students. The Euro CALL Review, 23(2), 3-18. https://doi.org/10.4995/eurocall.2015.4665

Barrot, J. S. (2016). Using Facebook-based e-portfolio in ESL writing classrooms: Impact and challenges. Language, Culture and Curriculum, 29(3), 286-301. https://doi.org/10.1080/07908318.2016.1143481

Bosch, T. E. (2009). Using online social networking for teaching and learning: Facebook use at the university of Cape Town. Communicatio, 35(2), 185-200. https://doi.org/10.1080/02500160903250648

Brown, H. D. (2007). Teaching by principles: An interactive approach to language pedagogy (3rd ed.). New York: Pearson Education.

Dja'far, V. H., Cahyono, B. Y., \& Bashtomi, Y. (2016). EFL teachers' perception of university students' motivation and ESP learning achievement. Journal of Education and Practice, 7(14), 28-37.

Ekoç, A. (2014). Facebook groups as a supporting tool for language classrooms. Turkish Online Journal of Distance Education, 15(3), 18-26. https://doi.org/10.17718/tojde.13403 
Gamble, C., \& Wilkins, M. (2014). Student attitudes and perceptions of using Facebook for language learning. Dimension, 13(5), 49-72.

Haverback, H. R. (2009). Facebook: Uncharted territory in a reading education classroom. Reading Today, 27(2), 34.

Kabilan, M. K., Ahmad, N., \& Abidin, M. J. (2010). Facebook: An online environment for learning of English in institutions of higher education? The Internet and Higher Education, 13(4), 179-187. https://doi.org/10.1016/j.iheduc.2010.07.003

Majid, A. H. A., Stapa, S. H., \& Keong, Y. C. (2012). Scaffolding through the blended approach: Improving the writing process and performance using Facebook. American Journal of Social Issues and Humanities, 2(5), 336-342.

Megawati, F., \& Anugerahwati, M. (2012). Comic strips: A study on the teaching of writing narrative texts to Indonesian EFL students. TEFLIN Journal, 23(2), 183-205.

Ping, N. S., \& Maniam, M. (2015). The effectiveness of Facebook group discussions on writing performance: A study in matriculation college. International Journal of Evaluation and Research in Education, 4(1), 30-37. https://doi.org/10.11591/ijere.v4i1.4489

Purwanti, T. T. (2015). The implementation of self-assessment in writing class: A case study at STBA LIA Jakarta. TEFLIN Journal: A publication on the teaching and learning of English, 26(1), 97-116. https://doi.org/10.15639/teflinjournal.v26i1/97-116

Razak, N. A., Saeed, M., \& Ahmad, Z. (2013). Adopting social networking sites (SNSs) as interactive communities among English foreign language (EFL) learners in writing: Opportunities and challenges. English Language Teaching, 6(11), 187-198. https://doi.org/10.5539/elt.v6n11p187

Sharples, M. (1999). How we write: Writing as creative design. London: Psychology Press.

Shen, Y. (2012). Reconsidering English grammar teaching for improving non-English majors' English writing ability. English Language Teaching, 5(11), 74-78. https://doi.org/10.5539/elt.v5n11p74

Shih, R., C. (2011). Can web 2.0 technology assist college students in learning English writing? integrating Facebook and peer assessment with blended learning. Australasian Journal of Educational Technology, 27(5), 829-845. doi:10.14742/ajet.934

Sumarsih, M., \& Sanjaya, D. (2013). TPS as an effective technique to enhance the students' achievement on writing descriptive text. English Language Teaching, 6(12), 106-113. https://doi.org/10.5539/elt.v6n12p106

Suthiwartnarueput, T., \& Wasanasomsithi, P. (2012). Effects of using Facebook as a medium for discussions of English grammar and writing of low-Intermediate EFL students. Electronic Journal of Foreign Language Teaching, 9(2), 194-214.

Taffs, K. H., \& Holt, J. I. (2013). Investigating student use and value of e-learning resources to develop academic writing within the discipline of environmental science. Journal of Geography in Higher Education, 37(4), 500-514. https://doi.org/10.1080/03098265.2013.801012

Tananuraksakul, N. (2015). An investigation into the impact of Facebook group usage on students' affect in language learning in a thai context. International Journal of Teaching and Learning in Higher Education, 27(2), 235-246.

Tiantong, M., \& Teemuangsai, S. (2013). The four scaffolding modules for collaborative problem-based learning through the computer network on moodle LMS for the computer programming course. International Education Studies, 6(5), 47-55. https://doi.org/10.5539/ies.v6n5p47

Wang, W. (2016). Peer feedback in Chinese college English writing class: Using action research to promote students' English writing. Journal of Language Teaching and Research, 7(5), 958-966. https://doi.org/10.17507/j1tr.0705.17

Woolfolk, A. (2001). Educational psychology (8th ed.). Boston: Allyn and Bacon.

Yunus, M. M., Salehi, H., Sun, C. H., Yen, J. Y. P., \& Li, L. (2011). Using Facebook groups in teaching ESL writing. Recent researches in Chemistry, Biology, Environment and Culture, 75(1), 75-80.

Yunus, M. M., \& Salehi, H. (2012). The effectiveness of Facebook groups on teaching and improving writing: Students' perceptions. International Journal of Education and Information Technologies, 1(6), 87-96. 
Yu, L. T. (2014). A case study of using Facebook in an EFL English writing class: The perspective of a writing teacher. JALT CALL Journal, 10(3), 189-202.

\section{Copyrights}

Copyright for this article is retained by the author(s), with first publication rights granted to the journal.

This is an open-access article distributed under the terms and conditions of the Creative Commons Attribution license (http://creativecommons.org/licenses/by/4.0/). 